\title{
KEARIFAN LOKAL MASYARAKAT DI KABUPATEN KAUR PROVINSI BENGKULU
}

\author{
THE LOCAL WISDOM OF SOCIETY \\ IN KAUR DISTRICT OF BENGKULU PROVINCE
}

\author{
Undri \\ Balai Pelestarian Nilai Budaya (BPNB) Sumatera Barat \\ Jl. Raya Belimbing nomor 16 A, Kuranji, Padang \\ E-mail:undri_siun@yahoo.com
}

\begin{abstract}
Abstrak
Tulisan ini memfokuskan tentang bentuk dan pengaruh kearifan lokal masyarakat pedesaan di Kabupaten Kaur Propinsi Bengkulu. Masyarakat di daerah tersebut memiliki kearifan lokal yang masih tetap eksis dan belum mengalami pelunturan dan bahkan sebagai penyangga sosial bagi upaya konservasi dan kelestarian sumber daya alam khususnya dalam bidang pertanian. Penelitian ini mengunakan metode penelitian sejarah. Dalam metode penelitian sejarah melalui empat tahapan penting yakni pertama heuristic, mencari dan menemukan sumber-sumber sejarah atau pengumpulan sumber, Kedua, kritik menilai otentik atau tidaknya suatu sumber dan seberapa jauh kredibilitas sumber. Ketiga, sintesis dari fakta yang diperoleh melalui kritik sumber atau disebut juga kredibilitas sumber, dan keempat, penyajian hasilnya dalam bentuk tertulis. Hasil penelitian diperoleh yakni masyarakat di Kabupaten Kaur Propinsi Bengkulu memiliki kearifan lokal dalam bidang pertanian yang disebut repung. Masyarakat menyediakan lahan di setiap marga untuk ditanami dengan tanaman pangan yang disebut repung. Bentuk kearifan lokal masyarakat di Kabupaten Kaur dapat dibagi dalam bentuk pertama, kearifan lokal dalam pertanian. Kedua, kearifan lokal dalam pengelolaan hutan. Pengaruh kearifan lokal terhadap kehidupan masyarakat pada lingkungan hidup masyarakat di Kaur, pengaruhnya dapat dibagi dua yakni positif dan nanti akan terjaganya kelestarian lingkungan hidup dan negatif, yakni terjadinya kerusakan lingkungan bagi masyarakat Kaur itu sendiri.
\end{abstract}

Kata Kunci : Kearifan lokal, repung, masyarakat Kaur

\begin{abstract}
This paper focuses on the shape and influence of local wisdom of rural communities in Kaur District of Bengkulu Province. The communities in the area have local wisdom that still exist and have not changed and even as a social buffer for conservation efforts and sustainability of natural resources, especially in the field of agriculture. This research uses historical research method. In historical research methods through four important stages: first heuristic, searching for and finding historical sources or collecting resources, Secondly, criticism assesses whether authentic or not a source and how much source credibility. Third, the synthesis of facts obtained through source criticism or credibility of the source, and fourth, the presentation of the results in written form. The result of this research is that people in Kaur District of Bengkulu Province have local wisdom in agriculture called repung. The community provides land in every clan to be planted with food crops called repung. The form of local wisdom of the community in Kaur District can be divided into the first form, local wisdom in agriculture. Second, local wisdom in forest management. The influence of local wisdom in the life of the community
\end{abstract}


in the environment of society in Kaur, its influence can be divided into two that is positive and will be preserved environmental sustainability and negative, that is environmental damage for the people of Kaur itself.

Keywords: Local wisdom, repung, Kaur society

\section{PENDAHULUAN}

Kajian ini tidak terlepas dari persoalan bahwa kearifan lokal di Indonesia kini menjadi topik bahasan menarik dibicarakan di tengah semakin menipisnya sumber daya alam, keprihatinan terhadap peningkatan intensitas kerusakan sumberdaya alam khususnya akibat berbagai faktor perilaku manusia, kepunahan pengetahuan yang menjadi basis adaptasi berbagai komunitas lokal, serta tekanan ekonomi yang makin menglobal mempengaruhi kehidupan masyarakat sehingga kearifan lokal mengalami pelunturan sebagai penyangga sosial (social buffer) bagi upaya kelestarian sumberdaya alam khususnya dalam bidang pertanian (Marfai, 2012; Santoso, 2006 : 6). Akibat semua itu mendorong masyararakat melakukan hal-hal yang bersifat destruktif terutama saat mengelola usaha produktif yang mengandalkan potensi sumber daya alam.Selain itu, kesadaran untuk kembali kepada kearifan lokal saat ini karena sering terjadi perubahan iklim yang tidak menguntungkan bagi manusia sehingga telah memungkin manusia harus dekat dengan lingkungannya (Putra 2008:2).

Kedekatan manusia secara fisik dan emosional dengan lingkungan sumberdaya alam serta terjadinya interaksi dalam suatu sistem yang menghasilkan proses saling berkaitan saling memberi dan mengambil kemanfaatan satu dengan yang lainnya dalam kurun waktu yang telah lama, melahirkan pemahaman dan pengetahuan tentang lingkungannya. Hasil proses interaksi yang menghasilkan pemahaman dan pengetahuan yang mendalam dengan didasari saling ketergantungan tersebut telah mendorong manusia menemukan bentuk penyikapan terhadap alam dan lingkungan yang paling ideal. Dalam tataran ini manusia menemukan apa yang disebut dengan kearifan lokal tersebut, terutama terkait dengan penyikapan manusia dengan alam serta pola adaptasi dan proses interaksi mereka.

Keanekaragaman pola-pola adaptasi dan proses-proses interaksi terhadap lingkungan hidup yang ada di dalam masyarakat yang diwariskan secara turun temurun telah ditransformasikan sebagai bentuk aturan-aturan dan tradisi yang menjadi pedoman dalam memanfaatkan sumberdaya alam. Dengan kata lain, bentuk-bentuk perilaku, respon dan tradisi yang telah menjadi bentuk-bentuk budaya manusia dapat digunakan untuk menumbuhkan kesadaran masyarakat terkait pengelolaan dan konservasi lingkungannya. 
Kearifan lokal itu sendiri merupakan modal utama masyarakat dalam membangun dirinya tanpa merusak tatanan sosial yang adaptif dengan lingkungan alam sekitarnya.Kearifan lokal dibangun dari nilai-nilai sosial yang dijunjung dalam struktur sosial masyarakat sendiri dan memiliki fungsi sebagai pedoman, pengontrol, dan rambu-rambu untuk berperilaku dalam berbagai dimensi kehidupan baik saat berhubungan dengan sesama maupun dengan alam.Sekarang eksistensi kearifan lokal dirasakan semakin memudar pada berbagai kelompok masyarakat.Salah satu kelompok masyarakat yang paling rawan mengalami pelunturan kearifan lokal adalah masyarakat pedesaan, yang semestinya sebagai penyangga sosial (social buffer) bagi upaya konservasi dan kelestarian sumber daya alam khususnya dalam bidang pertanian.

Uniknya sampai sekarang ini masyarakat di Kabupaten Kaur Propinsi Bengkulu memiliki pengetahuan dan kearifan lokal yang masih tetap eksis dan belum mengalami pelunturan dan bahkan sebagai penyangga sosial (social buffer) bagi upaya konservasi dan kelestarian sumber daya alam khususnya dalam bidang pertanian. Hal ini sesuai dengan pendapat Marfai (2012 : 33) bahwa hampir setiap kelompok masyarakat mempunyai sistem kearifan lokal tersendiri bahkan telah melahirkan inovasi pengelolaan lingkungan dan pemanfaatan sumerdaya alam yang unik berbasis adat dan budaya setempat.

Menurut Malik (2010 :10) sejak dahulu kearifan lokal di Kabupaten Kaur sudah terbentuk dan sudah eksis ratusan tahun.Masyarakat menyediakan lahan di setiap marga $a^{l}$ untuk ditanami dengan tanaman pangan yang disebut repung.Tanaman pangan di lahan repung terutama di tanami dengan tanaman penghasil karbohidrat dari umbi seperti Gadung, Talas, Ubi Rambat, Ubi Kayu, Gembili, dan lain-lain.Tanaman penghasil karbohidrat dari pohon seperti Sukun, Keluih, Nangka, Cempedak, Durian, Pisang, dan lain-lain.Tanaman penghasil sayuran seperti Melinjo, Kelor, Lempipi, Bambu, Rotan dan lain-lain.Repung ini sangat berfungsi ketika keadaan darurat yaitu ketika bahaya kelaparan mengancam.Pada saat itu kekurangan pangan sering terjadi ketika kemarau panjang melanda wilayah Kaur.Bukan itu saja, masyarakat di daerah ini pun memiliki kearifan lokal baik dalam bidang pertanian maupun pengelolaan hutan.

Berdasarkan sumber yang ada, keberadaan repung ini dapat ditelusuri yakni tahun 1930an. Memasuki tahun 1930 terjadi depresi ekonomi yang melanda dunia sehingga melumpuhkan tata perekonomian dan tata kehidupan sosial. Depresi ini melanda segala aspek usaha yang

\footnotetext{
${ }^{1}$ Marga adalah sistem pemerintahan terendah pada masa sebelum berlakunya Undang-Undang nomor 5 Tahun 1979 tentang Sistem Pemerintahan Desa dan Kelurahan. Sistem pemerintahan ini bentukan Kesultanan Palembang yang berlaku di wilayah kekuasaan Kesultanan Palembang termasuk Propinsi Bengkulu dan Lampung saat ini. Dalam hal repung, setiap marga memiliki luas lahan sekitar 2 (dua) sampai 5 (lima) hektar.
} 
telah sekian lama mapan dan melumpuhkan tiang kehidupan masyarakat. Awal tahun 1930-an keadaan ekonomi Indonesia semakin memburuk karena krisis dunia yang tidak reda-reda. Bagi rakyat, zaman malaise itu berarti pengurangan kesempatan kerja, pemotongan gaji, turunnya harga hasil-hasil pertanian, rendahnya upah buruh dan sebagainya (Nitisastro, 1970 :92).

Bertitik total dari persoalan di atas, kajian ini memfokuskan tentang kearifan lokal masyarakat pedesaan di Kabupaten Kaur Propinsi Bengkulu. Rumusan masalah dalam kajian ini yakni : (1) Bagaimana bentuk kearifan lokal masyarakat pedesaan di Kabupaten Kaur Propinsi Bengkulu?, dan (2) Bagaimana pengaruh kearifan lokal terhadap kehidupan masyarakat pedesaan di Kabupaten Kaur Propinsi Bengkulu?.

Sehubungan dengan rumusan masalah diatas, maka kajian ini bertujuan : (1) menjelaskan bentuk kearifan lokal masyarakat pedesaan di Kecamatan Kinal Kabupaten Kaur Propinsi Bengkulu, dan (2). menjelaskan pengaruh kearifan lokal terhadap kehidupan masyarakat pedesaan di Kecamatan Kinal Kabupaten Kaur Propinsi Bengkulu.

Adapun batasan spasial dalam pembahasan ini adalah Kabupaten Kaur Propinsi Bengkulu. Seperti yang telah dijelaskan pada bagian diatas bahwa masyarakat di daerah tersebut memiliki pengetahuan dan kearifan lokal yang masih tetap eksis dan belum mengalami pelunturan dan bahkan sebagai penyangga sosial (social buffer).

Batasan temporal dalam pembahasan ini dimulai sejak tahun 1930 dengan pertimbangan bahwa bahwa setelah depresi ekonomi terjadi kemerosotan dalam produksi beras, hal itu disebabkan adanya faktor eksternal yaitu seringnya Belanda berubah-ubah kebijakan terhadap produksi beras dan faktor internal yaitu petani yang kurang begitu bergairah menanam padi karena adanya musim kemarau. Dengan kondisi tersebut membuat masyarakat beralih kepada menanam tanaman pangan dikebun dengan melaksanakan repung. Sedangkan tahun 2016 diambil sebagai batasan akhirnya, karena proses sosial masih berlangsung sampai sekarang. Menurut Abdullah (2006), sebab proses sosial masih berlangsung dalam sebuah masyarakat, maka kajian ini tidak akan pernah berhenti dikaji, baik dari segi substansi isi maupun waktu.

\section{METODE PENELITIAN}

Penelitian ini mengunakan metode penelitian sejarah. Dalam metode penelitian sejarah akan melalui empat tahapan penting yakni pertama heuristic, mencari dan menemukan sumbersumber sejarah atau pengumpulan sumber, Kedua, kritik menilai otentik atau tidaknya sesuatu 
sumber dan seberapa jauh kredibilitas sumber. Ketiga, sintesis dari fakta yang diperoleh melalui kritik sumber atau disebut juga kredibilitas sumber, dan keempat, penyajian hasilnya dalam bentuk tertulis (Gottschalk, 1985 : 32 ; Kuntowijoyo, 1999 : 89).

Dalam pengumpulan sumber dilakukan melalui studi kepustakaan dan studi lapangan.Studi kepustakaan dilakukan pada Perpustakaan Daerah dan Arsip Kabupaten Kaur di Bintuhan, Kantor Perpustakaan dan Arsip Provinsi Bengkulu di Bengkulu, Perpustakaan Universitas Bengkulu di Bengkulu, Biro Pusat Statistik Propinsi Bengkulu di Bengkulu, Biro Pusat Statistik Kabupaten Kaur di Bintuhan, dan lainnya.

Untuk menutupi kekurangan dan keterbatasan sumber dan bahan tertulis tentang keadaan masyarakat digunakan sumber wawancara.Wawancara dilakukan terhadap sejumlah pendudukyang sezaman dengan kajian ini.Informan kunci (key informant) seperti tokoh adat.Wawancara juga dilakukan terhadap pihak pemerintah seperti kepala desa, camat, dan sebagainya.Hasil wawancara tersebut dilakukan pengujian data.Pengujian data akan dilakukan dengan wawancara silang guna mendapatkan data yang orisinil.

Tahap kedua, kritik yaitu tahap penyeleksian sumber-sumber sejarah.Meliputi kritik ekstern dan intern.Kritik ekstern ini dilakukan untuk menguji tingkat keabsahan sumber (otentisitas sumber) sedangkan kritik intern dilakukan untuk menguji tingkat kepercayaan sumber (kredibilitas sumber).Tahapan ini, melakukan kritik terhadap pendapat yang berbeda baik melalui tulisan sejarawan ataupun sumber lisan berupa wawancara antara pencerita yang satu dengan yang lainnya.Hal ini juga melakukan studi komparatif melalui arsip-arsip tertulis, foto-foto atau lukisan masa lampau lewat benda-benda peningalan sejarah.

Pada tahap ketiga dalam hal ini adalah interpretasi dalam arti merangkaikan fakta-fakta lainnya menjadi suatu kesatuan pengertian.Pada akhirnya fakta sejarah yang telah mempunyai makna tersebut dituliskan secara integral dalam suatu cerita sejarah.Tentu saja fakta sejarah yang sesuai dan ada relevannya dengan topik yang dibahas. 


\section{PEMBAHASAN}

\section{Gambaran Umum Daerah Penelitian}

Secara astronomis, Kabupaten Kaur terletak antara 1034' 8,76" - 10346'50,12" Bujur Timur dan 4'15'8,21" - 4º5 '27,77" Lintang Selatan. Wilayah kabupaten ini berada paling selatan dari wilayah Provinsi Bengkulu, berbatasan dengan Provinsi Sumatera Selatan dan Provinsi Lampung. Berdasarkan UU No.3 tahun 2003, secara administrasi Kabupaten Kaur berbatasan dengan yakni sebelah utara berbatasan dengan Kabupaten Bengkulu Selatan dan Kabupaten Lahan Propinsi Sumatera Selatan, sebelah selatan berbatasan dengan Kabupaten Lampung Barat Propinsi Lampung, sebelah barat berbatasan dengan Samudera Hindia, dan sebelah Timur berbatasan dengan Kabupaten Muara Enim, Kabupaten Ogan Komering Ulu Selatan, dan Kota Pagar Alam Propinsi Sumatera Selatan.

Kabupaten Kaur secara administratif memiliki luas 2.369,05 km². Luas wilayah Kabupaten Kaur di pesisir pantai pulau Sumatera mempunyai luas wilayah daratan 2 ribu 556 $\mathrm{Km} 2$ terdiri dari daerah daratan pesisir Pantai dan bukit bukit barisan dengan garis pantai sepanjang 106,6 Km dan luas kawasan laut sejauh 4 Mil dari garis pantai meliputi wilayah seluas 789,69 Km2. Jumlah penduduk Kabupaten Kaur berjumlah \pm 135.401 jiwa Kabupaten Kaur terdiri dari: 15 kecamatan, 4 kelurahan, 191 Desa (BPS, 2016 : 17).

Keadaan alamnya secara umum melandai ke barat dengan sisi sebelah Barat berupa dataran yang menghadap langsung ke Samudra Hindia.Sedangkan sisi sebelah Timur adalah daerah dataran tinggi yang merupakan pegunungan Bukit Barisan dengan ketinggian dapat mencai 1000 meter di atas permukaan laut.Dataran tinggi merupakan Taman Nasional Bukit Barisan Selatan.Sungai-sungai mengalir dan bermuara ke Samudera Hindia antara lain Air Sulau, Air Padang Guci, Air Serinjangan, Air Kinal, Air Luas, Air Sambat, dan Air tetap.Pada sungaisungai itu banyak mengandung batu-batu koral yang dapat menjadi bahan bangunan atau pengerasan jalan.Sementara di sepanjang pantai tumbuh pohon kelapa dengan pasir yang berwarna putih.Pantai-pantai menjadi andalan pariwisata di Kabupaten Kaur.Terdapat 11 pantai yang dapat dinikmati keindahannya antara lain Pantai Laguna, Pantai Sekunyit, Pantai Linau, Pantai Teluk Beringin, Pantai Muara Sambat, Pantai Way Hawang, Pantai Sullau, Pantai Bunga Karang, Pantai Hilli, Pantai Dayang Pandan, dan Pantai Cukoh. 
Disigi dari persoalan penduduk, penduduk Kaur terbentuk dari orang-orang yang berasal dari dataran tinggi Perbukitan Barisan, yaitu Orang Rejang dan Orang Pasemah (Palembang), Orang Lampung, dan Orang Minangkabau. Orang Minangkabau yang masuk melalui Indrapura masuk ke daerah Kaur (Bengkulu). Disini mereka bercampur dengan kelompok lain yang berasal dari Palembang, sehingga membentuk suatu identitas baru yaitu Orang Kaur (Sidarmin, 2016 : 20).

Sekarang ini, berdasarkan data Badan Pusat Statistik Kabupaten Kaur Tahun 2016 bahwa jumlah penduduk di Kecamatan Kinal yakni sebanyak 4.189 jiwa orang atau 3.62\% dari jumlah penduduk di Kabupaten Kaur, yakni 115.805 jiwa orang dengan luas daerah Kinal yakni 154.03 kilometer persegi atau $6.51 \%$ dari jumlah keseluruhan Kabupaten Kaur yakni 2.365 kilometer persegi. Berdasarkan angka statistik juga bahwa daerah ini memiliki kepadatang penduduk 27 orang per kilometer persegi (BPS, $2016: 25)$.

\section{Kearifan Lokal dalam Simboer Tjahaja Bangkahoeloe}

Persoalan kearifan lokal yang ada di Kabupaten Kaur sekarang ini tidak bisa dilepaskan dari undang-undang yang pernah berlaku di daerah tersebut, di Kaur khususnya dan Bengkulu umumnya. Menggali kearifan lokal di daerah ini bisa ditelusuri dari undang-undang yang pernah ada. Dalam buku Koempoelan Oendang-Oendang Adat Lembaga dari Sembilan Oenderafdeelingen dalam Gewest Bengkoelen (1993), dijelaskan bahwa undang-undang tersebut dimaktubkan pada tanggal 21 Februari 1862 oleh toen J. Wallad, Assisten Resident yang memimpin daerah pada masa itu. Saat Wallad memerintah dalam satu afdeling dikresidenan Palembang, beliau mengumpulkan beberapa aturan adat-istiadat di tanah huluan Palembang untuk dikirimkan kepada J.F.R.S vanden Bossche, Assisten Residen Tebing Tinggi, karena beliau dititahkan oleh Residen Palembang untuk mengarang sebuah buku undang-undang untuk tanah huluan dalam keresidenan tersebut. ${ }^{2}$

\footnotetext{
${ }^{2}$ Khusus di Palembang, Simbur Cahaya merupakan aturan yang berlaku sejak masa Kesultanan Palembang Darussalam untuk wilayah pedalaman (uluan), tetap berlaku pada masa kolonial Belanda, bahkan sampai periode awal kemerdekaan Republik Indonesia saat dihapuskannya sistem pemerintahan marga pada tahun 1979. Pada masa Kesultanan Palembang, aturan yang berlaku di daerah uluan, selain mengacu pada aturan tertulis yang kemudian dikenal sebagai Undang-undang Simbur Cahaya. Aturan yang pada awalnya dikenal dengan Piagem Ratu Sinuhun, ini konon ditulis dengan aksara lokal yang dikenal sebagai surat ulu, yang kemudian mengalami kompilasi dan dikodifikasi dalam suatu himpunan yang utuh, pernah diterbitkan menggunakan huruh Arab Melayu dan di antaranya menggunakan huruf latin. Berkenaan dengan Undang-Undang Simboer Tjahaya di Palembang lebih lanjut lihat karya Adil, $2011: 124$.
} 
J, Walland kemudian menetapkan undang-undang tersebut di daerah Bengkulu, kecuali daerah Mukomuko yang ketika itu masih dibawah pemerintahan sultannya.Dalam tahun 1862 itu juga di Mukomuko ditetapkan pula oleh sultan peraturan seperti itu, undang-undang Mukomuko namanya.Ini merupakan permintaan sendiri sultan Mukomuko terhadap Assisten Residen Walland (Hoesin, 1993: 224-230).

Secara jelas bahwa persoalan tentang kearifan lokal di daerah ini tidak terlepas dari sumber yang didapatkan dari Simboe Tjahaja Bangkahoeloe tersebut, khususnya Bab II tentang aturan dusun dan berladang, dijelaskan ;

Fatsal 6. Djika orang berladang bersangkoep atau berkeoboen tidak, serta tiada beri tahoekan pada orang jang poenja ladang, maka membakar ladangnja dan api melarap sampai pada orang lain poenja ladang, jang pangkal api, tinggi watas bahoe.

Kemudian dilanjutkan dengan, pasal 7 yang menjelaskan tentang denda yang akan dikenakan kepada perusak ladang, secara lebih jelas dapat dilihat pada penjelasan berikut ini, yakni ;

Fatsal 7. Djika orang membakar ladangnja maka orang yang poenja seperti doerian, kelapa, sirih, roempoen bambu atau lain roesak, ia kena denda dari tiga sampai enam, serta menganti tanaman jang roesak.

Bukan sebatas itu saja, di daerah ini aturan yang terdapat didalam Simboe Tjahaja Bangkahoeloe yang berkenaan dengan persoalan kearifan lokal juga termaktub dalam undangundang tersebut.

\section{Repung : Bentuk Kearifan Lokal Masyarakat dalam Bidang Pertanian ${ }^{3}$}

Segi historis, daerah tersebut secara ekologi merupakan penggabungan antara persawahan dan perladangan, penduduk mengupayakan kedua sektor ini.Di sawah ditanam padi sedangkan di ladang, di samping ditanami padi ladang juga ditanami tanaman komoditi ekspor seperti kopi, karet, dan sebagainya.Hal ini sangat terkait dengan kondisi letak tanah pertanian yang berada di daratan tinggi dan di daratan rendah sehingga berpengaruh pada jenis padi yang ditanam.Secara garis besar padi yang ditanam ada dua, yaitu padi sawah dan padi ladang.Sawah pada dasarnya mengandalkan suplai air. Paling tidak sawah ada beberapa jenis yaitu : sawah berbandar langit, sawah bernadar hidup, sawah ditanah rawa-rawa, sawah pasang surut, tegalan dan ladang atau huma (padi kering) yang tidak mengandalkan air. Sawah berbandar hidup terdapat hampir merata di seluruh daerah tersebut.Sawah ini secara rutin memperoleh pengairan baik melalui sarana kincir air atau bendungan sungai.Sawah berbandar langit selalu menggantungkan pasokan air dari air hujan. 
Di Kaur, proses penanaman padi sampai tahun 1935 telah maju dengan pesat, lahanlahan sawah bertambah luas, dan di beberapa daerah telah dibuka sawah baru dan sawah yang telah lama lama ditinggalkan kini digarap kembali, areal tanaman padi terus bertambah. Sampai tahun 1965, kondisi seperti masih dijalankan oleh sebagian masyarakat di daerah ini.Saat itu, daerah ini memiliki hamparan sawah \pm 200 hektar.Hamparan sawah tersebut telah menghiasi daerah ini dengan pemandangan yang sangat menakjubkan.Sawah-sawah yang ada di daerah tersebut pada umumnya dialiri air dari pegunungan yang ada disekitarnya.

Masyarakat di daerah ini sebagian besar sejak dulunya berprofesi sebagai petani padi dan masih mempertahankan cara menanam padi tradisional sehingga jumlah pupuk dan pembasmi hama berbahan kimia yang digunakan jauh lebih sedikit. Penanaman padi dilakukan dua kali dalam setahun. Waktu bertanam padi sengaja dilakukan secara serentak dengan tujuan untuk mengurangi serangan hama. Sebelum dibajak dan ditanami, sawah terlebih dahulu diberi pupuk berupa kotoran ternak.

Dalam bidang pertanian ini, masyarakat di Kaur mengenal istilah repung-sebagai salah satu bentuk kearifan lokal masyarakatnya.Repung sebagai salah-satu bentuk kearifan lokal, memiliki dimesisosial dan budaya yangkuat, karena memang lahirdari aktivitas perlakuan berpola manusia dalam kehidupan bermasyarakat. Sebab kearifan local dapat menjelma dalam berbagai bentuk sepertiide, gagasan, nilai, norma, dan peraturandalam ranah kebudayaan, sedangkan dalam kehidupan sosial dapat berupa sistem religius,sistem dan organisasi kemasyarakatan, system pengetahuan, sistem mata pencaharian hidupdan sistem teknologi dan peralatan (Koentjaraningrat, 1964). Hal ini berkaitan dengan perihal bahwa kearifan lokal yang diwujudkan dalam bentuk prilaku adaptasi mempunyai peran penting dalam pengurangan resiko bencana, seperti bencana kelaparan. Kearifan lokal yang berlaku dalam menghadapi dan menyikapi bencana yang akan datang. Kearifan lokal itu sendiri merupakan ekstraksi dari berbagai pengalaman yang bersifat turun temurun dari nenek moyang atau orang terdahulu yang telah mengalami kejadian bencana, seperti repung tersebut.

Repung adalah lahan yang disediakan oleh masyarakat untuk ditanami tanaman pangan oleh setiap marga.Lahan yang ditanami adalah tanaman penghasil karbohidrat.Repung ini sangat berfungsi ketika keadaan darurat yaitu ketika bahaya kelaparan mengancam.Pada saat itu kekurangan pangan sering terjadi ketika kemarau panjang melanda masyarakat Kaur.

Sebagai masyarakat yang hidup dipedesaan maka pekerjaan utama masyarakat Kaur sebagai petani. Merujuk pada Wolf (1983), ia mendefinisikan petanisebagai pemilik penggarap, 
merupakan golongan terbatas yang memilikilahan pertanian, menggarap sendiri lahan tersebut dalam rangkamenghasilkan produk, produk itu digunakan untuk memenuhi kebutuhanhidupnya, bukan untuk dijual sehingga dengan bercocok tanam, petanimemenuhi kebutuhan hidupnya (subsistensi) sehari-hari sekaligusmenunaikan surplus sosial dan ritualnya. Senada dengan itu, Scott (1983) mendefinisikan peasant atau petani lebih longgar, konseppeasant didefinisikan sebagai penduduk perdesaan yang bekerja sebagaipetani. Surplus yang ada tidak dikonsumsi habis menurut kebutuhankeluarga untuk surplus sosial dan ritual, namun sebagian dijual kepasar untuk memenuhi kebutuhan dasar petani yang lain (minyak tanah,garam, lauk-pauk, dan lainlain) agar terjaga terus dan aman sepanjangmasa.

Munculnya repung itu sendiri tidak terlepas bahwa pangan merupakan kebutuhan paling dasar kehidupan manusia dan persoalannya pangan adalah pertaruhan eksistensi suatu bangsa.Pangan bahkan lebih berat dan penting dari pada bedil sebagai ketahanan suatu bangsa.Tanpa bedil atau pesenjataan orang masih bisa berperang apalagi perang griliya.Tanpa pangan orang tidak mampu menggerakan persenjataan yang canggih sekalipun.

Berdasarkan sumber yang ada, keberadaan repung ini dapat ditelusuri yakni tahun 1930an. Memasuki tahun 1930 terjadi depresi ekonomi yang melanda dunia sehingga melumpuhkan tata perekonomian dan tata kehidupan sosial.Depresi ini melanda segala aspek usaha yang telah sekian lama mapan dan melumpuhkan tiang kehidupan masyarakat. Awal tahun 1930-an keadaan ekonomi Indonesia semakin memburuk karena krisis dunia yang tidak reda-reda. Bagi rakyat, zaman malaise itu berarti pengurangan kesempatan kerja, pemotongan gaji, turunnya harga hasil-hasil pertanian, rendahnya upah buruh dan sebagainya (Nitisastro, 1970 :92).

Kesemuanya itu sebagai akibat dari politik ekonomi yang pada satu pihak menjalankan penghematan secara besar besaran dan pihak lain hendak mempertahan pendapatan ekspor terutama yang diperoleh dari hasil perkebunan. Dalam ekonomi yang dualistis pihak perekonomian tradisionalah yang memperoleh tekanan paling berat.Pada satu sisi ekonomi pertanian tradisional dapat berfungsi sebagai wadah pengaman di mana sebagian besar tenaga kerja kembali mencari nafkahnya pada waktu mulai tumbuh banyak perkebunan rakyat, khususnya perkebunan karet. (Kartodirdjo, 1990 : 179). Disamping menghadapi kesulitan ekonomi maka politik keras yang sedang ditempuh oleh kaum pergerakan Indonesia tidak ada alternatif lain kecuali mengubah haluan dari non-kooperatif menjadi kooperatif.

Daerah-daerah luar Jawa terutama Jambi, Sumatera Selatan, Kalimantan Selatan tergantung pada karet, berbeda dengan Jawa yang memusatkan perekonomiannya pada perkebunan-perkebunan tebu. Ketergantungan Jawa pada satu jenis tanaman ekspor ini 
menyebabkan kemunduran ekonomi Jawa pada waktu terjadi depresi ekonomi tahun 1930 (Mubiyarto, 1986 :216). Sedangkan kekuatan ekonomi wilayah Bengkulu khususnya Kaur pada umumnya terletak pada pengolahan sumberdaya alam yang bersumber dari sektor pertanian.Kegiatan yang terpenting di Kaur sejak dulu berasal dari pertanian baik yang menghasilkan bahan pangan maupun tanaman komersil.

Keadaan perekonomian Kaur masih tetap mampu bertahan selama depresi ekonomi, dalam arti mereka terbebas dari kekurangan bahan makanan pokok sehingga para petani mempunyai pilihan-pilihan ekonomis yang relatif fleksibel, sehingga ketika terjadi depresi ekonomi tidak begitu memukul kehidupan rakyat.Perihal ini tidak terlepas bahwa masyarakat menyediakan lahan di setiap marga untuk ditanami dengan tanaman pangan yang disebut repung.Repung ini sangat berfungsi ketika keadaan darurat yaitu ketika bahaya kelaparan mengancam, seperti pada zaman malaise tersebut.

Pada zaman pendudukan tentara Jepang, dimana tujuan pendudukan tentara Jepang tidak terlepas untuk kepentingan ekonomi Jepang menghadapi Perang Dunia ke II.Tidak jarang, banyak tanah-tanah yang dimiliki oleh pemerintah kolonial Belanda sebelumnya diambil alih oleh pendudukan tentara Jepang untuk biaya perang.Selain itu, untuk menghadapi Perang Dunia ke II, mereka juga membuat jalan-jalan jalur perdagangan.Untuk tenaga kerja yang cukup besar didapat secara paksa sebagai tenaga suka rela.Dikenal dengan tenaga kerja romusha.Di samping itu mereka dipaksa untuk membuat pertahanan-pertahanan meliter, lapangan-lapangan udara dan sebagainya.Mereka hidup dalam penyiksaan tanpa diberi makanan, tempat penginapan dan pengobatan.Belum pernah rakyat mengalami penderitaan dan penghinaan lahir dan bathin sehebat itu.

Pembongkaran tanaman pertanian dan perkebunan diganti dengan tanmaan plawija seperti jagung, kacang dan umbi-umbian, hampir seluruh pelosok tanah air yang diduduki Jepang. Tujuan Jepang melakukan propoganda ini adalah untuk kepentingan ekonomi Jepang menghadapi Perang Dunia ke II. Selain pergantian produktifitas bahan pangan dari lahan perkebunan adalah usaha untuk membuat jalan-jalan jalur perdagangan dan membuat jalan kereta api dari pedalaman menuju pantai. Untuk tenaga kerja yang cukup besar di dapat secara paksa sebagai tenaga suka rela yang dikenal dengan tenaga kerja Romusha (Syofiarni, 1997 :82).

Dalam hal pemilikan lahan pada masa pemerintah Jepang, masih terlihat pada kepemilikan lahan yang disesuaikan dengan status tanahnya. Bagi masyarakat di daerah tersebut , hutan masih tetap merupakan milik dari anggota kaum. Banyak tanah-tanah yang dimiliki 
oleh pemerintahan kolonial Belanda sebelumnya di ambil oleh tentara pendudukan Jepang, hal tersebut tidak terlepas untuk membiayai perang mereka. Semua perkebunan milik pemerintah kolonial Belanda sebelumnya diambil oleh tentara pendudukan Jepang, begitu juga dengan perusahaan milik Belanda.

Dalam zaman pendudukan tentara Jepang ini, kuatnya dominasi tentara Jepang dalam mengeksploitir tenaga rakyat seperti untuk Romusha, membuat konflik tersebut seakan-akan "buntu" karena rakyat telah menjadi ajang eksploitasi sehari-hari oleh tentara pendudukan Jepang. Walaupun demikian halnya, diberbagai daerah hal ini juga terjadi misalnya di Jawa Timur adanya pristiwa Blitar (1944) dan di Jawa Barat pristiwa Singaparna dalam tahun yang sama terjadi konflik akibat petani yang dieksploitir dan hasil panennya disita oleh tentara Jepang(Tjondronegoro, $1999: 83-84)$

Padi yang dihasilkan oleh rakyat diambil secara paksa oleh tentara pendudukan Jepang.Hal ini membuat rakyat menjadi ajang eksploitasi sehari-hari oleh tentara Jepang.Di daerah Kaur, pendudukan tentara Jepang mengambil paksa hasil panen masyarakat berupa padi. Menurut Rani (1991 :45) dan Siddik (1996 :560 bahwa kondisi masyarakat pada saat tersebut mengalami kelaparan. Namun, masyarakat akhirnya mencari alternatif untuk melaksanakan repung, yang jaraknya dari pemukiman sekitar lebih kurang 10 sampai 15 kilometer.Kondisi ini telah memungkinkan mereka dapat mengolah lahan tersebut sebagai alternative untuk mencukupi kebutuhan pangan.

Pemerintah pendudukan Jepang memandang produksi beras sebagai bagian terpenting dalam membangun ketahanan pangan di wilayah-wilayah yang didudukinya. Otoritas Jepang mempunyai keyakinan kuat bahwa pertanian pangan di Jawa mempunyai potensi pasar dan dengan mengadopsi teknologi pertanian yang telah dikembangkan dalam pertanian di Jepang, potensi besar yang dimiliki Jawa akan dapat direalisasikan secara nyata.

Sejak berdiri tegak setelah revolusi berakhir, Republik Indonesia menghadapi keadaan ekonomi yang kurang menguntungkan, antara lain mewarisi keuangan Federal dan Republik Indonesia Yogyakarta dengan deficit besar, kecendrungan inflasi kuat, bahkan tidak seimbang antara ekspor dan impor. Proses pemulihaan perkebunan berjalan lambat dan selama perang, Indonesia telah kehilangan sebagian besar pasarannya sebelum perang. Kemerosotan produksi tidak mendukung untuk segera mengejar ketinggalan atau memulihkan pasaran dunia(Kartodirjo dan Djoko Suryo, 1991:162). 
Dalam banyak catatan sejarah, telah diungkapkan bagaimana eksploitasi yang dilakukan pemerintah kolonial terhadap tanah dan tenaga kerja rakyat Indonesia. Dimulai dengan penerapan sistem sewa tanah, cultuurstelsel, hingga diterapkan Undang-undang Agraria 1870, rakyat Indonesia telah kehilangan hak atas tanah yang telah lama dikuasai oleh nenek moyangnya. Bahkan pemerintah kolonial memandang tanah sebagai "alat pengikat "bagi penanaman modal asing perkebunan. Tanah telah dipandanf sebagai komoditas strategi dalam upaya menarik modal asing.

Ketika Indonesia merdeka ini, keberadaan repung ini besar manfaatnya.Wilayah Kaur dilanda musim kemarau, hasil panen padi gagal.Menurut Djawatan Penerangan Republik Indonesia (1954) sawah yang ada di Kaur seluas 97.1 hektar hanya menghasilkan padi sebesar 13.5 ton.Hal ini tidak mencukupi kebutuhan masyarakat Kaur.Kemudian masyarakat melaksanakan repung tersebut, yakni menanam tanaman pangan pada lahan mereka yang berada pada lokasi kebun yang ketergantungannya pada hujan sangat sedikit bila dibandingkan dengan tanaman padi. Mereka menanam Gadung, Talas, Ubi Rambat, Ubi Kayu, Gembili, Sukun, Keluih, Nangka, Cempedak, Durian, Pisang, Melinjo, Kelor, Lempipi, Bambu, Rotan dan lain-lain.

Hal yang sangat menarik terjadi tahun 1967 secara nasional begitu juga dengan daerah Kaur diawali dengan pertanda yang menggembirakan dengan adanya panen padi musim hujan yang baik dan pembelian beras dalam negeri yang cukup besar. Namun ternyata pertanda ini hanyalah pertanda yang semu. Pada awal bulan September tahun itu, panen beras musim kering ternyata menunjukkan penurunan tajam sebagai akibat musim kering panjang yang melanda Asia Tenggara ((Mears dan Sidik Moeljono dalam Booth dan Peter McCawley, 1981 : 38-39). Krisis beras pada tahun 1967 tersebut mengisyaratkan perlu adanya alternatif bagi masyarakat untuk melangsungkan hidupnya.Hingga pada waktu itu, repung juga menjadi penopang kehidupan masyarakat Kaur.

Namun setelah itu yakni tahun 1969 sampai tahun 1979 dengan konsep Repelita I dan Repelita II, Orde Baru kemudian memberikan tekanan pada bidang produksi dan konsumsi beras, dan terkenal dengan kebijakan swasembada berasnya (Mears dan Sidik Moeljono dalam Booth dan Peter McCawley, 1981 : 29). Pemerintah Orde Baru menyadari pentingnya persediaan beras yang cukup. Dalam hal inilah kemudian dilaksanakan kebijakan Gerakan Revolusi Hijau yang dikenal sebagai program Bimas dan Inmas, ${ }^{4}$ sebuah kebijakan yang dijalankan oleh rezim Orde Baru dan telah mendapat kritikan sejalan dengan meningkatnya kesadaran akan kelestarian lingkungan karena mengakibatkan kerusakan lingkungan yang parah. Sebab dengan adanya kebijakan tersebut telah mengunakan teknologi yang tidak memandang kaidah-kaidah lokal 
guna menuju swasembada pangan.Seperti pengunaan pemakaian pupuk kimiadanpestisida, dan lainnya.Melalui penerapan teknologi non-tradisional ini, diharapkan terjadi peningkatan hasil tanaman pangan berlipat ganda dan memungkinkan penanaman tiga kali dalam setahun untuk padi pada tempat-tempat tertentu, suatu hal yang sebelumnya tidak mungkin terjadi. Bahkan menurut Indrizal dan Hazwan (1993), hal itu berkaitan erat dengan revolusi biru yangmenunjuk pada perubahan pola penggunaan teknologi untuk menghasil produksi yang lebih tinggi.

Pada masa Orde Lama, dengan berlanjutnya kekacauan politik dan konflik meliter antara kekuatan Republik dengan kekuatan kolonialisme Belanda rupanya membuat produksi bahan pangan penduduk mengalami kemunduran.Infrastruktur dan jaringan irigasi terus mengalami kemerosotan karena tidak adanya investasi dan pemeliharaan. Namun demikian, pemerintah tidak tinggal diam. Untuk mewujudkan tercapainya swasembada pangan rakyat Indonesia, pemerintah menyusun rencana produksi bahan pangan selama tiga tahun (1948-1950) yang diluncurkan di Jogjakarta pada 1948 dan dikenal dengan sebutan "Kasimo Plan". Rencana yang disusun Menteri Urusan Bahan Makanan Kasimo ini merupakan usaha menuju terwujudnya swasembada pangan dengan petunjuk implementasi secara riil dan praktis.Kasimo merekomendasikan agar tanah-tanah kosong yang terdapat di Sumatera Timur seluas 281.277 hektar ditanami dengan bahan pangan.

Kemudian langkah yang kongrit dalam rangka mewujudkan swasembada beras adalah peluncuran program padi sentra (1955-1959). Ada 4 (empat) kegiatan pokok terkait dengan program padi sentra, yakni (1).Memanfaatkan dan memulihkan kembali kesuburan lahan-lahan kering, (2).Melakukan perluasan areal penanaman padi, (3).Pengembangan wilayah, dan (4).Mengurangi kepadatan penduduk di Jawa melalui program transmigrasi.

Gerakan Swasembada Bahan Makanan pada tahun 1963/1964 diupayakan melalui penyelenggaraan pusat-pusat intensifikasi, yang juga menjadi pusat bimbingan koperasi produksi pertanian. Selain kebijakan terkait dengan peningkatan produksi beras, politik pangan pada masa pemerintah Orde Lama juga menyentuh berbagai aspek pengaturan distribusi. Tujuannya adalah untuk menjamin bahan pangan sampai pada para konsumen.Pada musim panen pemerintah melakukan pengadaan beras dengan membeli secara langsung dari para petani.Beras yang berhasil dikumpulkan agen-agen pemerintah selanjutnya disimpan di gudang-gudang selama beberapa waktu untuk kemudian dilepas ke pasar pada saat persediaan bahan makanan dalam rumah tangga penduduk menipis dan langka, yang secara tradisional dikenal sebagai musim paceklik. Dengan cara ini potensi terjadinya krisis pangan, terutama di wilayah-wilayah 
yang dikenal sebagai daerah defisit beras, diluar musim pangan bias dikurangi melalui kegiatan yang popular disebut pada 1950-an sebagai “injeksi beras” (Margono dan kawan-kawan, 2010)

Pada masa Orde Baru telah ada kebijakan dan upaya pemerintah untuk meningkatkan produksi bahan pangan yang vital untuk kelangsungan hidup rakyat dan stabilitas politik.Bahkan terwujudnya swasembada bahan pangan telah menjadi fokus yang ingin dituju melalui kebijakan dan implementasinya.

Pada awal tahun 1960-an produksi padi memperlihatkan penurunan. Berbagai faktor ikut bertanggungjawab atas penurunan produksi padi, termasuk di antaranya hama tikus yang secara tradisional terus menerus mengancam. Buruknya panen 1961 yang berakibat terjadinya krisis beras terutama kombinasi faktor abnormalitas iklim berupa kemarau panjang yang banyak mendatangkan kegagalan panen (Hutabarat, 1974 : 13-14).

Pada masa Orde Reformasi, gagasan tentang repung di Kaur oleh Herman Malik-seorang akademisi, birokrat yang menjadi Bupati Kaur periode Kaur (2004-2012), mengagas sebuah program yang bernama Lareka (Lahan Repung Kaur) tahun 2004. Memakai istilah repung yang pernah ada dalam budaya kearifan lokal masyarakat Kaur, pemerintah Kaur dibawah kepemimpinan Herman Malik mencanangkan kembali melalui program penanaman komoditas bahan pangan pada tanah pemerintah ditingkat kabupaten dan kecamatan dengan program Lareka tersebut. Komoditas pangan yang mulai dikembangkan pada Lareka adalah singkong. Pemilihan komoditas singkong ini karena kemampuan produksi singkong per satuan hektar sangat tinggi untuk daerah Kaur, yakni mencapai 80 ton per hektar (Malik, 2010 : 285).

Sebenarnya tanaman singkok hamper tersebar merata di daerah Kaur dengan varietas lokal. Varietas singkong Kaur merupakan varietas singkong manisyang rendah kandungan HCNnya, ${ }^{5}$ sehingga sehabis panen dapat langsung diolah sederhana untuk dikonsumsi. Namun, produktivitas singkong lokal ini lebih rendah, yaitu tanpa perlakukan teknologi, produktivitasnya sekitar 20 ton per hektar. ProgramLareka ini adalah penanaman singkong dengan mengintrodusir varietas singkong "pahit" yaitu singkong dengan mengandung kadar HCN yang tinggi, sehingga varietas singkong ini disebut sebagai singkong mengandung "racun". Keuntungan dari penanaman singkong "racun" pada program Lareka ini yaitu disamping produktivitasnya yang tinggi jauh melebihi varietas singkong lokal, singkong "racun" ini tidak begitu disukai oleh hama babi hutan. Kabupaten Kaur ditutupi oleh 61 (enam puluh satu) persen wilayah kehutanan, sehingga perkembangbiakan hama babi praktis tidak bisa dikendalikan oleh petani. 
Penanaman awal program Lareka dengan melibatkan Tentara Nasional Indonesia (TNI). Juga pemeliharaannya, terutama dari gangguan hama babi melibatkan TNI. Dasar pelibatan TNI dalam program Lareka ini karena salah satu tujuan dari Lareka adalah pengembangan cadangan pangan termasuk juga cadangan pangan untuk keamanan negara.Pengembangan Lareka di masyarakat juga telah dimulai dengan penanaman umbi-umbian pada lahan transmigran.Pengembangan lebih lanjut Lareka di masyarakat memerlukan mekanisasi sederhana, karena penanaman yang hanya mengandalkan tenaga manusia untuk persiapan lahan Lareka sulit mencapai target pengembangan. Tentunya bantuan alat dan mesin pengolah atau bajak lahan sangat diperlukan untuk mengakselarasi pengembangan Lareka di masyarakat.Pengembangan Lareka yang dikelola oleh Badan Ketahanan Pangan Kabupaten Kaur tidak hanya menjadi lumbung pangan di Kabupaten Kaur, tetapi juga sebagai pusat penyediaan bibit dan tekhnologi bagi masyarakat.

Lareka adalah pola budidaya pertanian hemat energy atau masukan energy dari luar system yang rendah. Limbah pertanian akan menjadi andalan input dalam system biosiklus, sehingga limbah pertanian akan diolah menjadi pupuk kompos. Limbah kulit singkong sebagai bahan utama pupuk kompos Lareka. Juga, limbah kulit kulit singkong akan dijadikan pakan ternak, dan limbah ternaknya akan menjadi bioaktivator dalam proses pengomposan kulit singkong. Pengembangan pertanian melalui program Lareka, juga harus diiringgi dengan program pertanian terpadu (pertanian tanaman pangan, perikanan, peternakan) atau mix farming.

Pengembangan Lareka sebagai lumbung pangan dan logistik on-farm, adalah kegiatan pencadangan pangan dan logistik di daerah yang berpotensi mengalami rawan pangan dengan mengembangkan cadangan pangan dalam bentuk tanaman budidaya di lapangan (on-farm), untuk antisipasi masa rawan pangan, secara terus menerus. Apabila tidak terjadi kerawanan pengan dalam kurun waktu tertentu, atau ketika produk segar yang dihasilkan melebihi kebutuhan suplai pangan ke konsumen, maka produk segar tersebut dapat dipasarkan untuk keperluan bahan baku industri pengolahan.

Lahan Repung Kabupaten Kaur dalam arti luas adalah Kaur sebagai wilayah produsen atau pemasok cadangan pangan lokal dan regional dalam bentuk segar, baik untuk dikonsumsi langsung oleh masyarakat maupun untuk digunakan sebagai bahan baku industri pengolahan pangan. Tujuan dari program Lahan Repung sebagai lumbung pangan on-farm Kabupaten Kaur adalah : (1). Mencadangkan pangan hidup on-farm untuk mengantisipasi kekurangan pangan (paceklik) pada skala regional Sumatera Bagian Selatan, (2) Menyediakan kawasan 
evakuasi bencana yang mandiri pangan, (3) Menyediakan pusat logistik on-farm daerah untuk menunjang kebutuhan pertahanan dan keamanan, dan (4) Menyediakan bahan baku industri pangan olahan (Malik, $2010: 10$ ).

\section{Kearifan Lokal dalam Pengelolaan Hutan}

Sebelum membahas tentang persoalan hutan, maka sangat menarik penjelas dari Setiyanto (2015:85), yakni :

Para kepala pribumi di Kaur mendapat bagian dari hasil hutan berupa gading gajah, sarang burung, getah karet, getah dammar, cula badak, dan sebagainya.Semua gading gajah yang panjangnya sampai satu kaki, gading gajah belang dengan tangkainya yang hitam, gading passak, gading goeroe, merupakan hak Pangeran Manna.Akan tetapi, penemunya dapat menebusnya dengan membayar $f 4$ (gulden), kecuali gading yang berukuran lebih kecil menjadi hak penemu tanpa bagi hasil. Untuk cula badak, peraturannya sama dengan gading gajah. Untuk tanduk putih dapat ditebus dengan uang sebesar $f 8$, sedangkan tanduk hitam $f$ 4. Untuk sarang burung, penemunya wajib menyerahkan sebesar $1 / 3$ bagian, sedangkan untuk getah karet dihitung 10 duit $(f 2)$ untuk setiap pikulnya.Untuk getah dammar ditetapkan sebesar 16 duit terpikul seberat 125 pon Amsterdam.Sepertiga dari hasil tersebut menjadi hak kepala, sedangkan kerbau liar dibagi-bagikan di antara kepala bawahan.

Dari penjelasan tersebut, sangatlah erat antara kehidupan masyarakat di Kaur atas keberadan hutan itu sendiri, terutama untuk menjaga kelangsungan hidup mereka.Bagi masyarakat yang ada disekitar hutan, hutan mempunyai makna tersendiri. Makna tersebut akan dia tafsirkan menurut pengalaman serta pengetahuan mereka masing-masing. Ketika makna tersebut ditafsirkan ke dalam kehidupan nyata maka melahirkan berbagai macam aturan-aturan dan kebiasaan. Aturan-aturan dan kebiasaan tersebut mengikat semua anggota masyarakat, mulai dari tingkat paling bawah yakni keluarga, sampai kepada pemuka masyarakat serta seluruh anggota masyarakat. Semuanya akan patuh kepada "persepsi" yang mereka buat tersebut, yaitu oleh karena mereka mengangap bahwa kalau melanggar akan mendapat sangsi atas perbuatannya, biasanya berupa bencana dan sebagainya.

Berkenaan dengan cara atau strategi masyarakat menyelamatkan kawasan hutan, maka banyak ungkapan-ungakapan yang lahir, atau dongeng-dongeng yang apabila ditafsirkan secara ilmiah hanyalah berupa mitos dan khayalan belaka. Hal ini didasarkan terutama oleh karena semua itu sulit untuk dibuktikan, meskipun mempunyai makna tersendiri.apabila ungkapanungakapan dan dongeng tersebut dilangar maka yang tahayul atau irasional tersebut menjadi sebuah kenyataan, tepatnya sebuah realita yang tidak dapat dipungkiri lagi keberadaanya. 
Ungkapan-ungkapan dan dongeng-dongeng yang hidup dalam masyarakat tidak diketahui siapa yang pernah mengemukakan pertama kalinya.Namun demikian, ungkapan-ungkapan dan dongeng tersebut merupakan indikator yang baik tentang pendapat umum dari masyarakat tersebut. Ungkapan dan donggeng tidak sepantasnya dinilai sebagai dalil ilmiah yang penuh tanggung jawab dalam arti ketat, tetapi harus dinggap sebagai endapan pengalaman yang tumbuh menjadi semacamkebijaksanaan umum, yang pada gilirannya akan diturunkan secara dengan cara lisan. Lewat endapan pengalaman tersebutlah tumbuh suatu kebiasaan.

Pada masyarakat Kaur, kearifan lokal dalam pengelolaan hutan dapat dalam bentuk yakni : Pertama,cara-cara memadamkan api. Secara umum cara-cara memadamkan api yang ditemui adalah sama yaitu berdasarkan pengelompokan tinggi api dan luasnya penjalaran api. Namun sepanjang pengetahuan mereka, pada zaman dahulu tidak ada api besar, sehingga saat ini jika menghadapi api besar mereka hanya menonton, karena menurut pendapat mereka, memadamkan api besar sama dengan membuang tenaga sia-sia. Dalam menghadapi api kecil, kebiasaan mereka adalah menyembur dengan air menggunakan ember atau memukul api menggunakan rantingranting pohon atau ikatan dedaunan.

Kedua, aturan adat bagi orang membakar sembarangan. Pengetahuan masyarakat menunjukan bahwa nilai-nilai kearifan mengelola api secara tertib masih ada. Denda diberikan kepada siapa saja yang melakukan pembakaran lahan sembarangan dan mengakibatkan kebakaran di tempat lain seperti ladang dan kebun orang lain apalagi sampai masuk ke pemukiman mereka.

Sebelum melakukan pembakaran, masing-masing anggota kelompok membersihkan sekat bakar yang telah dibuat sebelumnya dengan menggunakan alat tebas berupa parang dan sebatang kayu untuk mengumpulkan bahan bahan bakar pada sekat bakar dipindahkan ke tengah areal ladang yang akan dibakar. Bahan bakar lainnya berupa vegetasi semak dan pohon kecil didalam ladang ditebas hingga rebah.Selanjutnya dikeringkan selama beberapa minggu. Setelah sekat dianggap aman maka salah satu anggota kelompok memulai membakar menggunakan alat korek api, obor bambu, atau obor yang dibuat dari ikatan rumput-rumputan yang sudah kering. Pembakaran dilakukan berlawanan dengan arah angin.

Pengelolaan hutan dalam adat dan kebiasaan yang dimiliki oleh masyarakat terdapat kegiatan yang dilarang untuk dilakukan karena dapat merusak fungsi hutan yaitu sebagai sumber 
air yang dapat menyebabkan kelestarian lingkungan terganggu (Njurumana, 2006).Pernyataan tersebut sesuai dengan hal-hal yang diterapkan oleh masyarakat dalam melindungi dan menjaga hutan adat tersebut.Terdapat kearifan lokal dalam bentuk larangan yang ditaati oleh masyarakat adat, seperti (1) Tidak boleh menebang pohon, (2). Tidak boleh memanfaatkan hasil hutan tanpa seizin ninik mamak, (3) Tidak boleh memanfaatkan hasil hutan secara berlebihan, (4) Tidak boleh menjual hasil hutan larangan, (5) Tidak boleh takabur dan sombong selama di kawasan hutan, (6) Tidak boleh berburu fauna hutan larangan, (7) Tidak boleh berbuat yang tidak baik di dalam hutan larangan, dan (8) Tidak boleh berkata-kata yang tidak baik di dalam hutan.

Sesuai dengan pendapat Prasetyo (2006), menyebutkan pada beberapa kasus pengelolaan hutan oleh masyarakat dapat dicermati bahwa kearifan masyarakat di dalam pengelolaan hutan pada kenyataannya telah membawa dampak yang positif bagi kelestarian hutan, karena mereka mempunyai tingkat ketergantungan dari hutan itu, sehingga pola-pola pemanfaatan lebih mengarah pada kelestarian, yang berupa (1) ajakan untuk saling menjaga kelestarian hutan dan menjaga satwa serta tanaman langka, (2) ajakan untuk tetap bertanggung jawab dalam hidup ini, dan (3) Masyarakat agar menanam tanaman yang dapat menjaga dan mengatur debitnya air di areal tanah garapan yang berbatasan langsung dengan hutan, seperti tanaman karet serta memanfaatkan debit air tersebut

Kepedulian masyarakat adat terhadap hutan dituangkan dan diterapkan dalam kearifan lokal ini.Kekayaan alam begitu pentingnya harus dijaga demi kelestariannya.Masyarakat membuat kolam-kolam ikan untuk melindungi keberadaan ikan dan sebagai bentuk pemanfaatan air dari hutan adat ini bahkan menjadikan sebagai salah satu mata pencaharian.Dari segi bercocok tanam, juga dianjurkan untuk memanfaatkan lahan dengan sebaik-baiknya, seperti menerapkan tumpang sari (agroforestry dan agrofishery).Tanaman karet merupakan tanaman pilihan yang ditanam di sekitar hutan khususnya, karena bertujuan untuk mengatur dan menjaga debitnya air dari hutan adat yang mengalir ke sungai-sungai di sepanjang pemukiman penduduk.Pada kawasan yang berbukit, tanaman karet juga menjadi tanaman pilihan untuk menghindari bencana alam, seperti tanah longsor.

Masyarakat di daerah tersebut secara keseluruhan telah memahami akan pentingnya kelestarian hutan larangan adat ini, ditandai dengan ketergantungan kehidupan masyarakat 
dengan hutan larangan, ketersediaan air bersih yang bergantung kepada hutan larangan dan terdapatnya tanaman kehutanan di sekitar pemukiman masyarakat sebagai bentuk ketaatan terhadap peraturan adat serta usaha untuk menjaga keseimbangan hutan larangan. Pemahaman akan perlindungan hutan juga telah mereka pahami, ditandai dengan ketaatan terhadap peraturan adat, beragamnya tanaman kehutanan yang ditanam oleh masyarakat dan pemanfaatan hasil hutan yang secara lestari. Sosialisasi untuk menjaga keberlanjutan kearifan lokal ini juga merupakan gambaran akan kepedulian terhadap kelestarian hutan larangan. Sosialisasi yang dilakukan seperti dilibatkannya anak-anak muda dalam prosesi adat dan pemberitahuan akan ajakan, larangan dan peraturan-peraturan adat kepada anak-anak muda dalam perkumpulanperkumpulan adat.

Kemudian, mengenai pengetahuan masyarakat tentang lingkungan yang mewarnai kehidupan tersebut, dapat dilihat dari uraian berikut ini: Pertama, pengetahuan tentang gejala alam.Pengetahuan mengenai gejala-gejala alam misalnya pengetahuan tentang musim-musim, tentang sifat-sifat dari gejala-gejala alam dan sebagainya.Pengetahuan tersebut biasanya berasal dari kebutuhan praktis untuk bertani, berkebun dan lain-lain.Pada masyarakat Kaur pengetahuan tersebut sudah mulai berkurang atau terlupakan. Sebagaimana yang diungkapkan oleh tokohtokoh desa, banyak pengetahuan yang merupakan warisan dari orang terdahulu pada perekembangannya sudah kurang diketahui sesuai perkembangan atau perjalanan zaman yang lebih mengarah pada perkembangan cara berpikir manusia yang realistis dan praktis. Hal ini sebenarnya dapat dipahami mengingat kecenderungan masyarakat dewasa ini pada hal-hal yang sifatnya baru (moderen).Nilai-nilai lama yang berupa penegatahuan masyarakat mengenai lingkungan sulit untuk diketahui lagi.Perlu penelusuran kembali, sebagai upaya untuk mengetahui sejauh mana masyarakat Kaur berinteraksi dan terintegrasi dengan lingkungannya.

Meskipin demikian, pengetahuan masyarakat tentang gejala-gejala alam dan waktu-waktu terjadinya gejala-gejala alam dapat diketahui mereka semata-mata berdasarkan pengamatan dan pengalaman mereka terutama tentang pergantian musim (penghujan dan kemarau).Pengalaman ini kemudian mereka ingat dan mereka pergunakan sesuai dengan kebutuhan hidup terutama dalam usaha-usaha atau kegiatan dalam bidang pertanian, terutama bertanam padi di sawah. 
Masyarakat pun mengetahui peredaran bintang-bintang di langit, terutama pengetahuan yang dipergunakan menentukan permulaan untuk turun mengolah sawaha atau ladang dan kebun.Sistem perhitungan ini terutama digunakan untuk menentukan hari baik atau hari buruk dalam penyelenggaraan suatu upacara adat ataupun yang berkaitan dengan pertanian termasuk memulai penanaman dan pemanenan.

Jadi dengan demikian, pengetahuan tentang gejala-gejala alam seperti tersebut di atas, yakni musim, bintang dan tanda-tanda tertentu tentang alam dijadikan sebagai penanda yang didasarkan pada pengamatan-pengamatan mereka. Namun dalam kenyataannya, pengetahuan tentang berbagai gejala alam ini terutama mengenai tanda-tanda alam tidak selalu makbul atau sesuai dengan apa yang diperkirakan. Ada yang tidak cocok atau tidak terjadi sama sekali, tetapi hal ini tidak dijadikan sebagai alasan pengurangan kepercayaan terhadap gejala tersebut, bahkan semakin diyakini oleh mereka atas keterbatasan pengetahuan yang mereka miliki sebagai makhluk Tuhan.

Musim hujan merupakan musim yang diharapkan, sebagai musim untuk bercocok tanam.Namun demikian, bukan berartti musim kemarau tidak disenangi.Hanya saja pada musim kemarau, kegiatan bercocok tanam terutama padi tidak bisa terlaksana karena kekurangan air, sementara sebagian besar lahan persawahan di daerah ini sifatnya tadah hujan.Ada kalanya ketika musim penghujan datang, sungai meluap, sehingga tanaman padi banyak mengalami kerusakan dan berujung pada kerugian yang harus ditanggung oleh petani.

Kedua, pengetahuan tentang lingkungan flora.Seperti diketahui masyarakat yang pada umumnya bermata pencaharian pokok dari pertanian, maka pengetahuan mereka dalam bertani tentunya didasarkan dari hasil pengamatan dan pengalaman.Oleh karena itu, dalam melakukan pengolahan sawah sebagaimana yang diutarakan pada bagian terdahulu, mereka sesuaikan dengan pergantian musim.

Dalam cara mengolah sawah, mereka mempergunakan alat-alat yang biasa dipakai oleh para petani pada umumnya misalnya cangkul dan sebagainya. Sedangkan alat penebasnya berupa sabit Adapun cara pengolahannya adalah dengan menggunakan bajak yang dihela oleh kerbau atau lembu untuk membalik tanah persawahan. Selanjutnya tanah tersebut dihaluskan dan digemburkan dengan menggunakan cangkul.Setelah areal persawahan sudah diperkirakan gembur, maka benih padi yang ada dipersemaian mulai dicabut lalu ditanam kembali pada 
areal tersebut.Ada pula dengan melakukan penanaman langsung yakni dengan menggunakan sistem tabur.

Ketiga, pengetahuan tentang lingkungan fauna.Pengetahuan tentang alam fauna juga merupakan pengetahuan dasar bagi masyarakat yang hidup dari pertanian.Daging binatang merupakan unsur penting dalam menu makanan masyarakat bertani juga.Selain itu petani harus juga banyak mengetahui tentang kelakuan binatang, untuk bisa menjaga tumbuh-tumbuhan di ladangnya.Masyarakat mengetahui bagaimana hewan peliharaan itu harus diperlakukan, seperti memelihara dan memanfaatkannya.Adapun masyarakat di daerah ini pada umummya memelihara ayam, kambing, lembu dan kerbau. Sebagai hewan peliharaan mereka mengetahui bagaimana cara memeliharanya yakni merawat dan memberi makan minum kepada ternaknya. Sedangkan manfaat dari hewan ternak tersebut selain untuk dikomsumsi juga dipergunakan untuk perayaan, misalnya hajatan perkawinan, upacara pesta panen maupun upacara-uapacara yang berkaitan dengan daur hidup.

Adapun ternak peliharaan berupa kerbau, lembu dan kambing biasanya digembalakan pada lahan-lahan terbuka.Kemudian pada malam harinya diikat lalu ditambatkan di areal terbuka tersebut agar tidak berkeliaran mengganggu tanaman.Sedangkan ayam pada umumnya tidak dipelihara dalam kandang, tetapi dibiarkan bebas mencari makanan sendiri.Pemberian makanan berupa dedak hanya diberikan pada waktu pagi.

Keempat, pengetahuan tentang lingkungan fisik.Lingkungan fisik dari manusia antara lain sungai, udara, air, rumah dan lainnya. Lingkungan menurut idealnya bukan hanya sekedar objek yang harus digunakannya untuk memenuhi dan mengetahui kebutuhan manusia (human centries), melainkan ia juga harus dipelihara dan ditata demi kelestarian lingkungan itu sendiri (eco centries).

Pada masyarakat didaerah ini, pengetahuan terhadap lingkungan fisik sudah ada sejak dahulu. Hal ini terbukti dengan dapat dilihatnya dari penataan lingkungan dan penataan lahan perkampungan mereka serta bagaimana cara menata dan mengatur tata tertib hidup masyarakat dengan menyesuaikan kondisi alam sekelilingnya. 


\section{Pengaruh Kearifan Lokal Terhadap Kehidupan Masyarakat}

Sebelum dijelaskan tentang persoalan pengaruh kearifan lokal terhadap kehidupan masyarakat pedesaan di Kaur, terlebih dahulu dijelaskan tentang persoalan lingkungan sebagai bagian dari kehidupannya. Jadi, lingkungan yang dihadapi oleh manusia pada dasarnya adalah yang telah dipahami, yanga mana pemahaman ini berbeda satu sama lain. Hasil pemahaman inilah yang membimbing manusia berperilaku dalam menghadapi lingkungan tersebut. Dengan demikian keraifan lokal merupakan produksi sejarah masyarakat lokal dalam rangka beradaptasi dengan lingkungannya (Sukari dan kawan-kawan, $2008: 3$ ).

Sistem pengetahuan yang merupakan salah-satu unsur kebudayaan tersebut muncul dari pengalaman-pengalaman individu yang disebabkan oleh adanya interaksi di antara mereka dalam menanggapi lingkungannya.Pengalaman-pengalaman manusia yang dilakukan secara berulang-ulang itulah yang kemudian menjelma menjadi kearifan lokal.Pengalaman itu diabstraksikan menjadi konsep-konsep, pendirian-pendirian atau pedoman-pedoman masyarakat dalam melakoni hidupnya. Selain itu, sistem pengetahuan sebagai salah-satu bagian dari pedoman hidup manusia diwariskan secara turun temurun, dari generasi ke generasi melalui proses belajar atau sosialisasi baik di lingkungan keluarga sebagai wahana pendidikan yang pertama dan utama, maupun pada level yang lebih luas yakni lingkungan pergaulan.

Sistem pengetahuan yang berkaitan dengan kearifan lokal dan diwariskan ke generasi berikutnya, seperti kearifan dalam bidang pertanian dengan repungnya telah menjadikan masyarakat di Kaur dekat dengan lingkungannya.Repung sebagai bagian dari kearifan lokal masyarakat telah menjadi penyangga hidup mereka ketika terjadi musim kemarau.Sebab lahan repung yang ditanami adalah tanaman penghasil karbohidrat.Repung ini sangat berfungsi ketika keadaan darurat yaitu ketika bahaya kelaparan mengancam.

Begitu juga dalam pengelolaan hutan, dengan adanya sistem pengetahuan yang mereka miliki dan menjadi sebuah kearifan lokal menyebabkan hutan terjaga dengan baik. Sebab masyarakat di daerah tersebut telah memahami akan pentingnya kelestarian hutan, ditandai dengan ketergantungan kehidupan masyarakat dengan hutan, ketersediaan air bersih, air untuk sawah yang bergantung kepada hutan tersebut Pemahaman akan perlindungan hutan juga telah mereka pahami, ditandai dengan ketaatan terhadap peraturan adat, beragamnya tanaman kehutanan yang ditanam oleh masyarakat dan pemanfaatan hasil hutan yang secara lestari. 


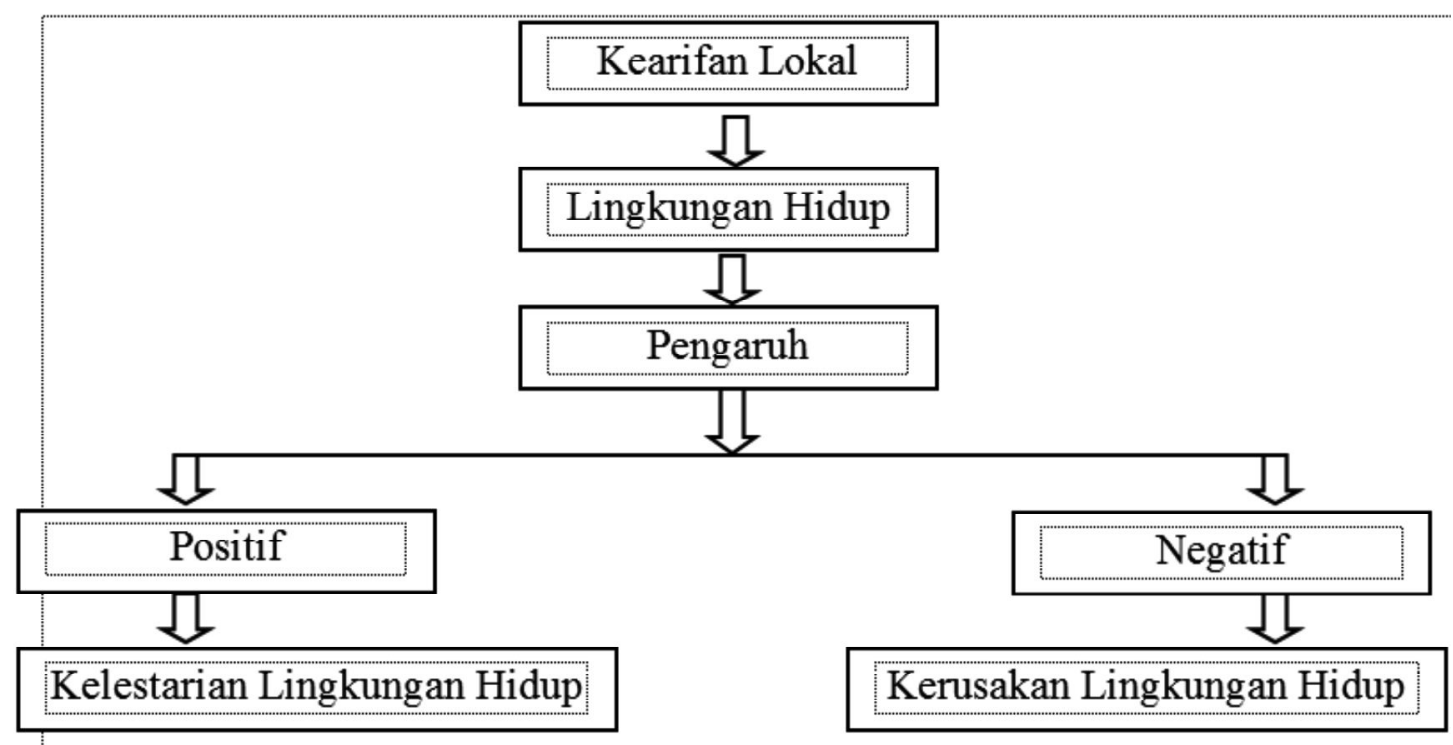

Diagram

Dampak dari kearifan lokal

\section{PENUTUP}

Berdasarkan persoalan yang telah dikemukan diatas bahwa masyarakat di Kabupaten Kaur Propinsi Bengkulu memiliki kearifan lokal yang masih tetap eksis dan belum mengalami pelunturan dan bahkan sebagai penyangga sosial (social buffer) bagi upaya konservasi dan kelestarian sumber daya alam khususnya dalam bidang pertanian dan bidang kehutanan.

Persoalan kearifan lokal yang ada di Kabupaten Kaur sekarang ini tidak bisa dilepaskan dari undang-undang yang pernah berlaku di daerah tersebut, Kaur khususnya dan Bengkulu umumnya, yakni Simboe Tjahaja Bangkahoeloe. Secara jelas bahwa persoalan tentang kearifan lokal di daerah ini tidak terlepas dari sumber yang didapatkan dari Simboe Tjahaja Bangkahoeloe tersebut, khususnya bab dua tentang aturan dusun dan berladang.Kemudian dilanjutkan dengan, pasal 7 (tujuh) yang menjelaskan tentang denda yang akan dikenakan kepada perusak ladang.

Bentuk kearifan lokal masyarakat di Kabupaten Kaur dapat dibagi dalam bentuk pertama, kearifan lokal dalam bidang pertanian.Di daerah Kaur kearifan local ini dinamakan dengan repung.Masyarakat menyediakan lahan di setiap marga untuk ditanami dengan tanaman pangan yang disebut repung.Tanaman pangan di lahan repung terutama di tanami dengan tanaman penghasil karbohidrat dari umbi seperti gadung, talas, ubi rambat, ubi kayu, gembili, dan lain-lain.Tanaman penghasil karbohidrat dari pohon seperti sukun, keluih, nangka, cempedak, durian, pisang, dan lain-lain.Tanaman penghasil sayuran seperti melinjo, kelor, lempipi, bambu, 
rotan dan lain-lain.Repung ini sangat berfungsi ketika keadaan darurat yaitu ketika bahaya kelaparan mengancam.Pada saat itu kekurangan pangan sering terjadi ketika kemarau panjang melanda wilayah Kaur, sebagai sebuah bentuk kearifan lokal.

Kedua, kearifan lokal dalam pengelolaan hutan.Hal ini tidak terlepas dari persoalan bahwa bagi masyarakat yang ada disekitar hutan, hutan mempunyai makna tersendiri. Makna tersebut akan dia tafsirkan menurut pengalaman serta pengetahuan mereka masing-masing. Ketika makna tersebut ditafsirkan ke dalam kehidupan nyata maka melahirkan berbagai macam aturan-aturan dan kebiasaan. Aturan-aturan dan kebiasaan tersebut mengikat semua anggota masyarakat, mulai dari tingkat paling bawah yakni keluarga, sampai kepada pemuka masyarakat serta seluruh anggota masyarakat. Semuanya akan patuh kepada "persepsi" yang mereka buat tersebut, yaitu oleh karena mereka mengangap bahwa kalau melanggar akan mendapat sangsi atas perbuatannya, biasanya berupa bencana dan sebagainya.

Pada masyarakat Kaur, kearifan lokal dalam pengelolaan hutan dapat dalam bentuk yakni (1).cara memadamkan api,, (2). aturan adat bagi orang membakar sembarangan, (3). kearifan lokal dalam bentuk larangan, (4). kearifan lokal dalam bentuk ajakan. Kemudian, mengenai pengetahuan masyarakat tentang lingkungan yang mewarnai kehidupan tersebut, yakni (1).pengetahuan tentang gejala-gejala alam, (2). pengetahuan tentang lingkungan flora, (3). pengetahaun tentang lingkungan fauna, (4). pengetahuan tentang lingkungan fisik

Pengaruh kearifan lokal terhadap kehidupan masyarakat pada lingkungan hidup masyarakat di Kaur, pengaruhnya dapat dibagi dua yakni positif dan nanti akan terjaganya kelestarian lingkungan hidup dan negatif, yakni terjadinya kerusakan lingkungan.

Pentingnya pelestarian kearifan lokal khususnya kearifan lokal pada bidang persawahan dan kehutanan untuk meningkatkan kesejahteraan masyarakat di Kabupaten Kaur Propinsi Bengkulu.

\section{DAFTAR PUSTAKA}

Abdullah,Irwan, 2006. Konstruksi dan Reproduksi Kebudayaan. Yogyakarta : Pustaka Pelajar.

Adil. 2011. Simboer Tjahaya : Studi tentang Pergumulan Hukum Islam dan Hukum Adat dalam Kesultanan Palembang Darussalam. Jakarta : Kementerian Agama RI Badan Penelitian dan Pengembang dan Pendidikan dan Latihan Pusat Penelitian Lektur dan Khazanah Keagamaan.

Ahimsa Putra, HS, 2008. "Ilmuwan Budaya dan Revitalisasi Keraifan Lokal Tantangan Teoritis dan Metodologis".Makalah disampaikan pada Rapat Senat Terbuka Dies Natalis ke 62 Fakultas Ilmu Budaya UGM.Yogyakarta. 
Booth, Anne dan Peter Mc Cawley.1981. Ekonomi Orde Baru.Jakarta : LP3ES.

Badan Pusat Statistik. 2016. Kaur dalam Angka Tahun 2015.Kaur : Badan Pusat Statistik Kabupaten Kaur Propinsi Bengkulu.

Gottschalk, Louis, 1985. Mengerti Sejarah. Terjemahan oleh Nugroho Notosusanto.Jakarta : Universitas Indonesia Press.

Hoesin, Ki Agoes. 1996 (cetak ulang).Koempoelan Oendang-Oendang Lembaga dan Sosial Oenderafdeeling dee Gewest Bengkoeloe.Palembang : Sriwijaya Media Oetama.

Hutabarat, Arifin, 1974. Usaha Mengatasi Krisis Beras.Jakarta : Lembaga Pendidikan dan Konsultasi Pers.

Indrizal, Edi. dan Hazwan. 1993. Desa-Desa Perbatasan TNKS: Kajian Sosial Ekonomi Masyarakat Pedesaan Hutan.Padang : PSLH Unand.

Kuntowijoyo, 1999.Pengantar Ilmu Sejarah. Jakarta : Yayasan Bentang Budaya.

Kartodirdjo, Sartono. 1990.Pengantar Sejarah Indonesia Baru : Sejarah Pergerakan Nasional dari Kolonialisme sampai Nasionalisme Jilid 2. Jakarta : Gramedia.

Kartodirjo, Sartono dan Djoko Suryo. 1991.Sejarah perkebunan di Indonesia : Kajian sosial-ekonomi. Yogyakarta : Aditya Media.

Koentjaraningrat. 1964. Pengantar Ilmu Antropologi. Jakarta: Penerbit Aksara Baru.

Malik, Erman. 2010. MelepasPerangkap Impor Pangan : Model Pembangunan Kedaulatan Pangan di Kabupaten Kaur, Bengkulu. Jakarta : LP3ES.

Marfai, Muh Aris. 2012. Pengantar Etika Lingkungan dan Kearifan Lokal.Yogyakarta : Gadjah Mada University Press.

Margono, Sri dan kawan-kawan. 2010. Sejarah Pangan di Indonesia : Strategi dan Politik Pangan dari Masa Kolonial Sampai Reformasi.Jakarta : Direktorat Geografi Direktorat Jenderal Sejarah dan Purbakala Kementerian Kebudayaan dan Pariwisata.

Mubiyarto. 1986. Pengantar Ekonomi Pertanian.Jakarta : LP3ES.

Nitisastro, Widjojo. 1970. Population Trends in Indonesia. Cornell University Press.

Njurumana, G.ND, 2006, Ekspose Hasil Hasil Penelitian Kehutanan Kerjasama BP2KBNT dengan Balitbangda Propinsi NTT dan Undana Kupang Tanggal 14 Februari 2006 dalam https:// media.neliti.com/media/publications/159576-ID-kajian-pendekatan-rehabilitasi-lahan-kri.pdf

Djawatan Penerangan Republik Indonesia. 1954. Propinsi Sumatera Selatan. Jakarta : Djawatan Penerangan Republik Indonesia.

Ranni, M.Z, 1991. Perlawanan Terhadap Penjajah dan Perjuangan Menegakkan Kemerdekaan Indonesia di Bumi Bengkulu. Jakarta : Balai Pustaka.

Santoso, Imam. 2006. Eksistensi Kearifan Lokal Pada Petani Tepian Hutan Dalam Memelihara Kelestarian Ekosistem Sumber Daya Hutandalam Jurnal Wawasan, Februari 2006, Volume 11, Nomor 3.

Scott, James. 1983. Senjatanya Orang-Orang Yang Kalah.Jakarta: Yayasan Obor Indonesia.

Setiyanto, Agus.2015.Elite Pribumi Bengkulu Perspektif Sejarah Abad Ke-19.Jakarta : Balai Pustaka.

Sidik, Abdullah. 1996. Sejarah Bengkulu 1500-1990. Jakarta : Balai Pustaka. 
Sidarmin.2016. Permata Peradaban dalam Ragam Adat Kabupaten Kaur.Bintuhan : Pemerintah Kabupaten Kaur Bagian Kesejahteraan Rakyat Sekretaris Daerah Kabupaten Kaur Propinsi Bengkulu.

Sukari, 2008.Kearifan Lokal Petani Garam dan Tambak Ikan di Kalianget Madura dalam Jurnal Jantra Volume III nomor 5 Tahun 2008. Yogjakarta : Departemen Kebudayaan dan Pariwisata Balai Pelestarian Sejarah dan Nilai Tradisional Yogjakarta.

Syofiarni, 1997."Perkebunan karet orang Pandai Sikek di Lubuk Minturun (1915-1942)"Skripsi S1.Padang : Fakultas Sastra Universitas Andalas Padang.

Tjondronegoro, Sediono.M.P. 1999. Sosiologi Agraria : Kumpulan Tulisan Terpilih.. Bandung : Yayasan Akatiga.

Undri.2017. Repung dan Kearifan Lokal Masyarakat di Kabupaten Kaur, Bengkulu: Perspektif Sejarah dalam Sri Sugiharta, Sumatera Silang Budaya : Konstestasi Nilai-Nilai Historis, Arkeologis, Antropologis Serta Upaya Pelestarian Cagar Budaya. Batusangkar : Balai Pelestarian Cagar Budaya (BPCB) Sumatera Barat.

Undang-Undang nomor 5 Tahun 1979 tentangSistem Pemerintahan Desa dan Kelurahan.

Yudohusodo,Siswono.1998.Transmigrasi: Kebutuhan Negara Kepulauan BerpendudukanHeterogen dengan Persebaran yang Timpang. Jakarta: PT Jurnalindo AksaraGrafika.

Wolf, R. Eric. 1983. Petani : Suatu Tinjauan Antropologis.Jakarta : Rajawai Press. 